\title{
Short-term response of fish assemblages to instream habitat restoration in a heavily impacted streams
}

\author{
Correspondence: \\ Angelo Rodrigo Manzotti \\ armanzotti@gmail.com
}

\author{
${ }^{\oplus}$ Angelo Rodrigo Manzotti ${ }^{1},{ }^{\oplus}$ Mônica Ceneviva-Bastos ${ }^{2}$, \\ ${ }^{\bullet}$ Fabrício Barreto Teresa ${ }^{3}$ and ${ }^{\oplus}$ Lilian Casatti ${ }^{1}$
}

Habitat homogenization has been a major impact in stream ecosystems, and it is considered one of the main drivers of biotic homogenization as well, leading to the loss of water quality and fish diversity. In this study, we added artificial woody structures and leaf packs in physically impacted streams to test if the additions can improve habitat complexity and change the taxonomic and functional structure of fish communities. The experiment was done in eight streams impacted by siltation, deforestation, and habitat homogenization, inserted in an agricultural landscape from the Upper Paraná River Basin, and lasted 112 days. The provision of artificial microhabitats increased instream habitat diversity by creating patches of organic matter deposits, changing flow, and providing substrate for grass colonization of the instream habitat. The experimental manipulation also changed fish species abundance. Nine species contributed to these changes, five decreased and four increased in abundance, indicating species responded differently to the experimental manipulation. However, overall species richness, diversity, and community functional traits remained unaltered. These results indicate that short-term habitat restoration on a local scale may not be enough to promote changes in fish community attributes of streams that are heavily impacted.

Submitted August 20, 2018 Accepted February 13, 2020 by Fernando Pelicice Published April 20, 2020

Online version ISSN 1982-0224

Print version ISSN 1679-6225

Neotrop. Ichthyol.

vol. 18, no. 1, Maringá 2020

Epub, Apr 17, 2020
Keywords: Biodiversity, Habitat Management, Neotropical streams, Structural Complexity, Woody debris.
1 Departamento de Zoologia e Botânica, Universidade Estadual de São Paulo (UNESP), Rua Cristóvão Colombo Street, 2265, 15054-000 São José do Rio Preto, SP, Brazil. (ARM) armanzotti@gmail.com, (LC) licasatti@gmail.com

2 Departamento de Biologia, Universidade Estadual do Centro-Oeste (UNICENTRO), Rua Simeão Camargo Varela de Sa, 03, 85040-080 Guarapuava, PR, Brazil.mcbastos@gmail.com

3 Campus de Ciências Exatas e Tecnológicas, Universidade Estadual de Goiás (UEG), Rodovia BR-153, 3105, 75132-903 Anápolis, GO, Brazil. fabricioteresa@yahoo.com.br 
A homogeneização de habitats tem sido um importante impacto nos ecossistemas de riachos e também é considerada um dos principais fatores de homogeneização biótica, levando à perda da qualidade da água e da diversidade de peixes. Neste estudo, adicionamos estruturas artificiais de madeira e pacotes de folhas em riachos fisicamente impactados para testar se as adições podem aumentar a heterogeneidade do habitat e alterar a estrutura taxonômica e funcional das comunidades de peixes. O experimento foi realizado em oito riachos impactados por assoreamento, desmatamento e homogeneização de habitat, inseridos em uma paisagem agrícola da bacia do Alto Paraná, com duração de 112 dias. $\mathrm{O}$ fornecimento de microhabitats artificiais aumentou a diversidade de habitat criando manchas de depósitos de matéria orgânica, alterando o fluxo e fornecendo substrato para a colonização de grama no interior do canal. A manipulação experimental também alterou a abundância de espécies de peixes. Dentre as nove espécies que contribuíram para essas alterações, cinco diminuíram e quatro aumentaram em abundância, indicando que as espécies responderam diferentemente à manipulação experimental. No entanto, a riqueza geral de espécies, a diversidade e as características funcionais da comunidade permaneceram inalteradas. Esses resultados indicam que a restauração de habitat a curto prazo em escala local pode não ser suficiente para promover mudanças nos atributos da comunidade de córregos que são fortemente impactados.

Palavras-chave: Biodiversidade, Complexidade Estrutural, Gestão de Habitat, Madeira, Riachos Neotropicais.

\section{INTRODUCTION}

The riparian forest of stream ecosystems is responsible for maintaining water quality and instream habitat diversity, influencing the composition and trophic dynamics of aquatic communities (Pusey, Arthington, 2003; Lorion, Kennedy, 2009; Cetra et al., 2017). Therefore, the removal or modification of the riparian forest is one of the major impacts to stream ecosystems (Pusey, Arthington, 2003). Consequences include increased runoff, which promotes sediment inputs and accelerates stream siltation and substrate homogenization (Silva et al., 2007). Additionally, the channel becomes more exposed to sunlight, increasing water temperature and evaporation and reducing water depth (Pusey, Arthington, 2003; Sweeney, Newbold, 2014). Deforestation also disrupts the supply of allochthonous organic material (such as roots, leaf litter, and woody debris), reducing the availability of microhabitat patches critical to the occurrence of many fish species (Crook, Robertson, 1999; Neumann, Wildman, 2002; Bond, Lake, 2003). Finally, this set of changes favors the presence of generalist species (Casatti et al., 2015) and the loss of biotic integrity (see Pinto et al., 2006).

Woody debris from the riparian forest promotes physical complexity in aquatic environments. They influence stream hydraulic profile (Brooks et al., 2004; Paula et al., 2013; Roni et al., 2015) and contribute to organic matter retention, providing 
increased availability of food resources and shelter (Scealy et al., 2007; Schneider, Winemiller, 2008). These combined factors can influence ecological processes, such as organic matter breakdown and nutrient cycling (Lepori et al., 2005a; Flores et al., 2011). They can also enhance trophic interactions by promoting richness and abundance of macroinvertebrates (e.g., Ceneviva-Bastos et al., 2017). Therefore, woody debris and leaf litter can be a key factor for the maintenance of diversity in both natural and restored reaches (Neumann, Wildman, 2002; Selego et al., 2012). Thus, the foundation of several freshwater restoration projects worldwide (e.g., Pretty et al., 2003; Palmer et al., 2014) lies in the assumption that habitat complexity promotes biodiversity (Ricklefs, Schluter, 1993; Allan, Castillo, 2007). Studies in temperate regions revealed positive relationships between increased habitat complexity and fish richness, with relevant changes in fish functional groups (e.g., Bond, Lake, 2003; 2005; Schneider, Winemiller, 2008; Lorenz et al., 2013). However, other studies had demonstrated that the enhancement of structural complexity alone is not enough to improve the biotic quality of heavily impacted environments (e.g., Kondolf, 1998; Palmer et al., 2010; Flores et al., 2011; Langford et al., 2012).

In tropical streams, patterns of fish community responses to restoration are yet to be discovered because this knowledge is limited to few studies (e.g., Wright, Flecker, 2004). Besides, it is presumable to assume that fish community responses to restoration strategies in tropical streams may diverge from those observed in temperate streams, given that tropical streams have different sunlight conditions, temperature, organic material supply, and distinct trophic structure and ecosystem functioning (Boyero et al., 2009). In one of the first studies on experimental wood addition in the tropics, in an Andean piedmont stream, Wright, Flecker (2004) observed a marked increase in fish richness and abundance in the experimental stream reaches, and that fish composition became more similar to areas with naturally occurring woody debris. In Brazil, though, experimental studies concerning the effects of restoration on stream communities are restricted to the study of Ceneviva-Bastos et al. (2017), who found that the addition of woody debris and litter bags promoted food web complexity in terms of links and species, with macroinvertebrates responses more prominent than those of fish. Hence, our work is the first, to our knowledge, to target the responses of fish assemblages to habitat improvement.

Despite the scenario of intense deforestation (Achard et al., 2002) and biotic integrity loss in tropical streams (e.g., Pinto et al., 2006), even a few patches of riparian forest can contribute to the maintenance of more specialized and sensitive species (Lorion, Kennedy, 2009; Cruz et al., 2013), probably due to the provision of leaf litter and woody debris to the stream. In this context, we aimed to investigate if short-term stream restoration by the addition of woody structures and leaf packs can improve habitat complexity and change fish community and functional structure. We investigated the hypothesis that the addition of woody structures and leaf packs in simplified streams (i.e., impacted by deforestation, high siltation, and habitat homogenization) increases habitat complexity and changes fish taxonomic and functional structure. We predicted that the woody structures and leaf packs would: (1) increase water depth and velocity and increase habitat complexity; (2) increase fish richness and taxonomic diversity; (3) change the representativeness of trophic guilds and habitat use by fish. In this last case, we expected to find increased representativeness (richness and/or abundance) of 
nektonic drift feeders (due to increased amount of items dragged by the current), grazer detritivores (due to the increased supply of consolidated substrate and organic matter retention), substrate speculators (that use leaves and wood as shelter or foraging site), and predators (that exploit these refuges); and (4) change the functional richness and functional composition of the fish community.

\section{MATERIAL AND METHODS}

Study area. This study was conducted in northwestern São Paulo State, southeast Brazil (Fig. 1). The area belongs to the Serra Geral geological formation, with basaltic and sedimentary rocks of the Bauru and Cauiá groups and deep aquifers in the Botucatu and Pirambóia sand formations (IPT, 2018), which makes it highly susceptible to soil erosion (Silva et al., 2007). The climate is classified as tropical Aw type, with annual rainfall between 1,100-1,300 $\mathrm{mm}$ (Alvares et al., 2014). Native forest in the region occupies less than $6 \%$ of its original cover area, and it is limited to few, sparse, and unconnected forest fragments (Nalon et al., 2008).

We investigated the hypothesis by experimentally adding woody structures and leaf packs in eight second order streams from the Tietê, São José dos Dourados, and TurvoGrande watersheds, Upper Paraná River basin. We selected four streams from the Tietê basin (P1, P2, P6, and P7 streams), two from the São José dos Dourados (P3 and P4), and two from the Turvo-Grande (P5 and P8) (Fig. 1). All selected streams were inserted in pasture areas and were physically degraded, i.e., characterized by the absence of native forest cover along all streams, abundant grasses on their margins, homogeneous substrate (predominantly composed by sand, with > 80\% cover), and homogeneous mesohabitats, with the predominance of runs (i.e., intermediate conditions between shallow, fast-flowing habitats and deep, slow-flowing habitats, sensu Teresa, Casatti, 2012). This set of habitat features has been reported to be typical of highly impacted streams in the study region (Casatti et al., 2015).

Experimental design. The experiment was set in three 5-meter reaches of each stream, placed 25 meters apart from each other. These reaches corresponded to three different treatments: 'wood' (W), in which a wood structure was attached to the substrate; 'wood and leaf packs' (WL), in which a wood structure was installed with leaf-packs attached to it, and 'control' (C), which remained unaltered. Each 5-meter reach was considered a replica, so each stream had a replica of each condition $(\mathrm{C}, \mathrm{W}$ and WL). All treatments were set in a similar environment of stream degraded section. The display sequence of treatments was randomized among streams and each stream contained the three treatments. The experiment lasted 112 days, counting from day 1, when the experimental structures were installed, until day 112, when they were removed right before the beginning of the rainy season. The experimental periods hereafter are referred to as pre- and post-restoration periods.

Habitat assessment and fish sampling were carried out in all streams before day one and after 112 days. The control reaches in pre- and post-restoration periods remained unaltered by experimental manipulation, being subject only to natural variation. The $\mathrm{W}$ and WL reaches were similar to the control reach in the pre-restoration period, 


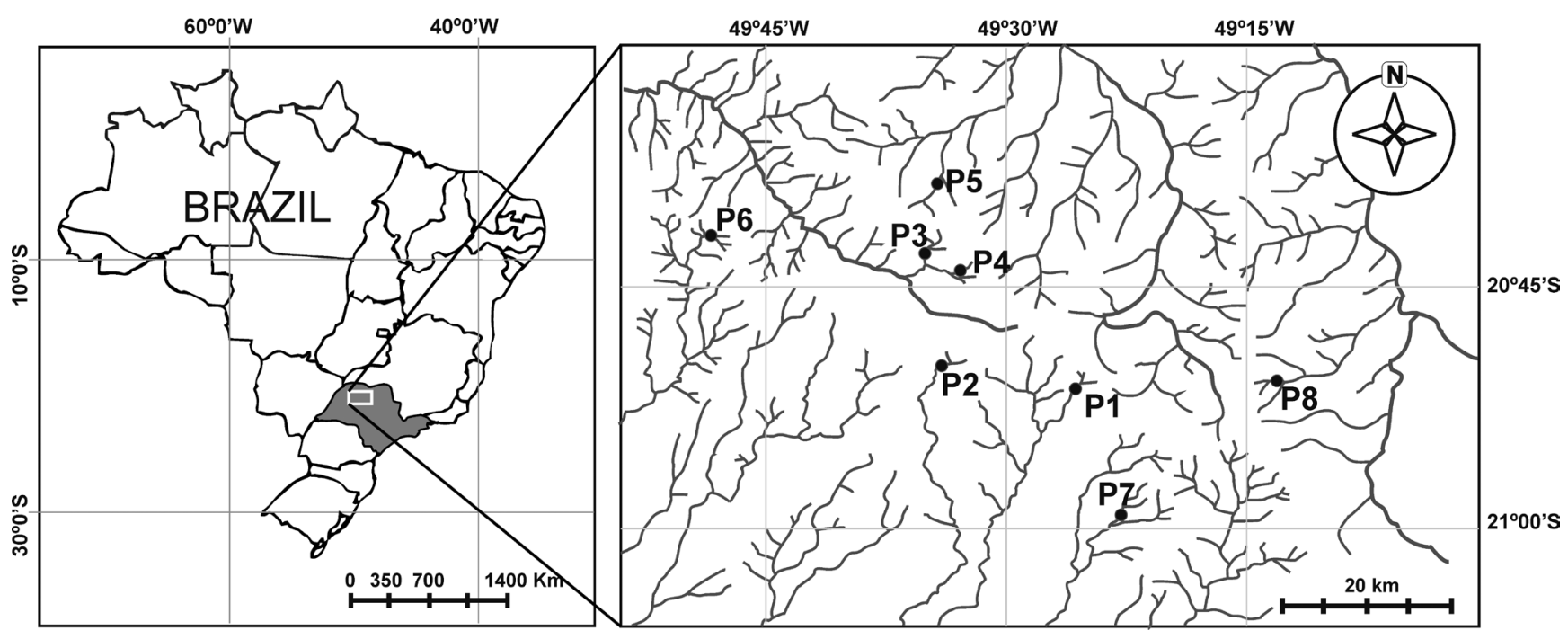

FIGURE 1 I Map of the study area, highlighting the state of São Paulo and the location of the streams within the watersheds: Tietê River (streams P1, P2, P6 and P7), São José dos Dourados River (P3 and P4), and Turvo River (P5 and P8).

though were subject to the effect of wood and wood and leaf-packs in the postrestoration period. The experiment was conducted between April and August 2011, the period of lowest rainfall (average accumulated precipitation was $20.6 \pm 22.3 \mathrm{~mm} /$ month - CIIAGRO, 2011), selected for favoring the experimental structure stability, the sampling procedure and for minimizing possible seasonal variations in fish assemblage structure.

Experimental settings. The wood structures consisted of eight wood slats $(1.2 \mathrm{x}$ $0.10 \times 0.01 \mathrm{~m})$ and four battens $(0.60 \times 0.10 \times 0.02 \mathrm{~m})$, arranged in two layers (top and bottom) with four slats each (see details in Fig. 2). For the WL reach, three of the four battens received a leaf pack $(0.10 \times 0.50 \mathrm{~m})$ with $21.87 \pm 1.32 \mathrm{~g}$ of native angiosperm leaf litter collected in the same region (Fig. 2). Litter bags and wood structures were used as surrogates of the original allochthonous material supply. The leaf packs were tied behind the battens, protected from floods.

We used eucalyptus masts ( $0.9 \mathrm{~m}$ length and $0.08 \mathrm{~m}$ diameter) to set the structure into the streams and prevent dragging from possible runoff events, which could compromise experimental progress. The masts were buried in stream banks and used to attach wires to bind the wood structure and prevented its horizontal displacement (Fig. 2). Also, five "U"-shaped iron rods ( $0.4 \mathrm{~m}$ length and $0.0127 \mathrm{~m}$ diameter) were used to fix the wood structure to the substrate, preventing its vertical movement (Fig. 2). The structures were installed near one of the margins and always in the center of the five-meter reach.

Habitat assessment. To assess the physical habitat structure of each reach, we measured channel width, depth and flow. Measurements were taken along three transverse transects in each of the five-meter stream reach. In each transect, three measurements were recorded: one near the left bank, one in the middle of the channel, and one near the right bank. We visually estimated the proportion of macrophyte types 


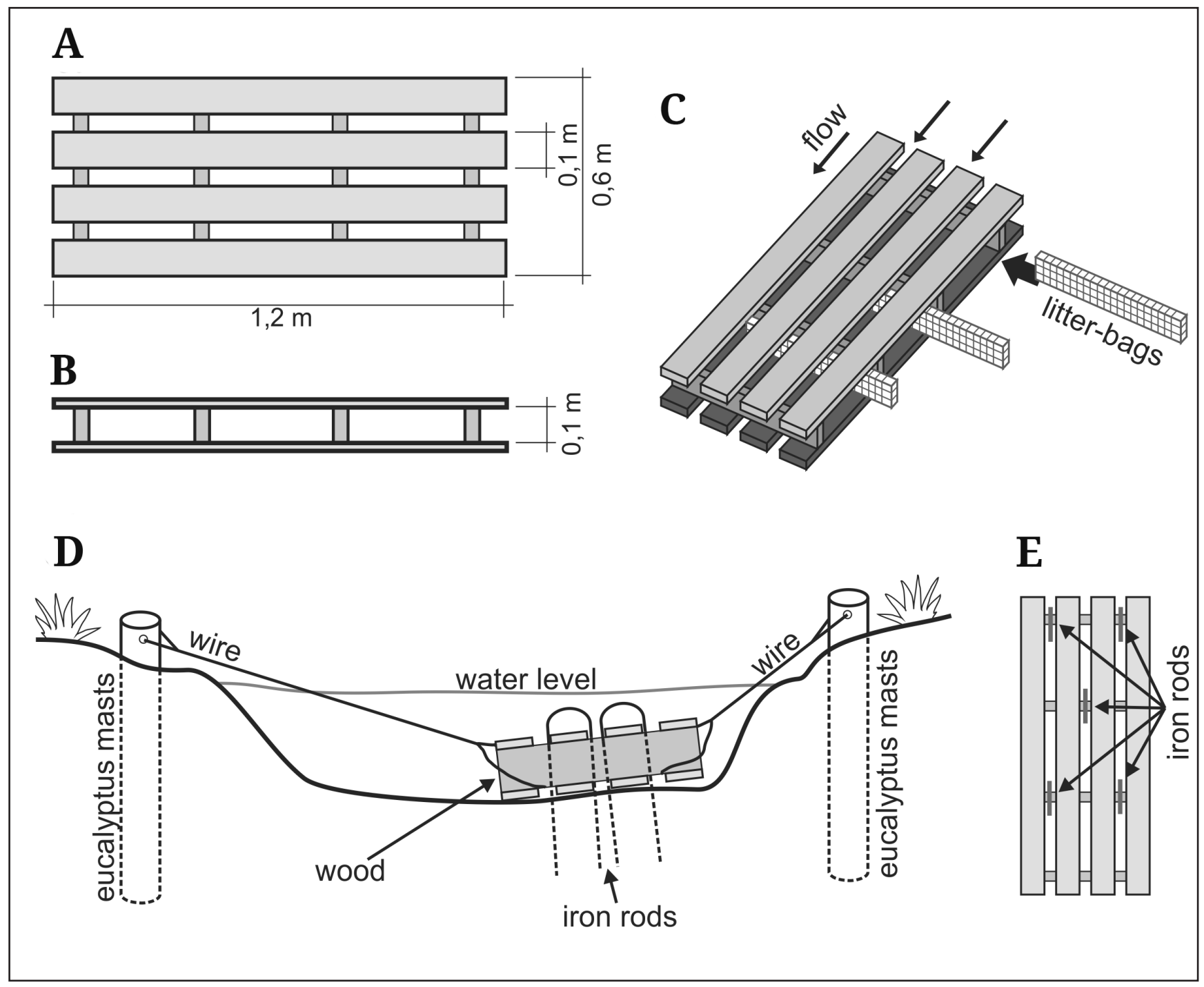

FIGURE 2 I Details of the structure used in the experiment. A. top view; B. side view; C. representation of the placement of the leaf-packs; D. cross section of the stream channel showing details of how the structure was placed in the stream; E. top view of the structure showing the points where the iron rods were installed.

(rooted, submerged or floating), algae (adhered or floating), litter, branches and trunks, and the proportion of different substrate types, classified according to particle size as silt $(<0.05 \mathrm{~mm})$, sand $(0.05-2.0 \mathrm{~mm})$, gravel $(2.0-10.0 \mathrm{~mm})$, pebble $(10.0-30.0 \mathrm{~mm})$, and rocks $(>30.0 \mathrm{~mm})$. These variables are considered important descriptors of habitat conditions, shelter and food availability for stream fishes (Gorman, Karr, 1978). In the visual evaluation, each descriptor analyzed received a percentage value according to its representativeness along a five-meter reach, with the sum of the percentages of all the variables totaling $100 \%$.

Instream habitat diversity was assessed using the Shannon-Wiener index, with habitat descriptors as variables. We also measured physical and chemical variables, such as water temperature, conductivity, dissolved oxygen, $\mathrm{pH}$, and turbidity with electronic 
equipment (Horiba, U-10 model). Physical and chemical variables were measured to ensure that any changes were due to experimental manipulation and not to changes in any of these parameters. The environmental assessment was performed in the pre- and post-restoration periods.

Fish sampling. Fish were sampled in each reach with the standardized effort of three electrofishing passes (stationary generator, AC, $220 \mathrm{~V}, 50-60 \mathrm{~Hz}, 3.4-4.1 \mathrm{~A}, 1,000$ W, see details in Castro et al., 2003) after blocking the upstream and downstream $5 \mathrm{~m}$ reach limits with 3-mm-mesh block nets. At the end of the experimental period, the electrofishing protocol was repeated, and the wood structures were removed from the stream and washed over a tray to collect fish specimens trapped therein. We identified fish species and their taxonomic position based on Reis et al. (2003), Britski et al. (2007), Buckup et al. (2007), Ota et al. (2018), and the "FishBase" (Froese, Pauly, 2019) and "CAS Catalog of fishes" (Frick et al. 2020) electronic databases. All captured specimens (license number 11435) were euthanized, by eugenol overexposure (300 mg/L), subsequently fixed in 10\% formalin solution and, after $48 \mathrm{~h}$, transferred to $70 \% \mathrm{EtOH}$ solution. Fish were deposited at the fish collection of IBILCE/UNESP (DZSJRP19173-19199).

Taxonomic and functional structure of fish assemblages. We used species richness and diversity to assess fish assemblage taxonomic structure. Richness was given by the number of species in each sampling unit and diversity was calculated using the Shannon-Wiener index. The functional structure of fish assemblages was assessed by describing species according to functional traits related to feeding and habitat use (Tab. 1). These important niche dimensions (Winemiller et al., 2015) are essential to explain the distribution of fish species along habitat complexity gradients (Ribeiro et al., 2016).

We used the mean pairwise distance (MPD) and the mean nearest taxon distance (MNTD) to characterize functional diversity in fish assemblages. First, we constructed a functional distance matrix using a generalization of the Gower coefficient, according to Pavoine et al. (2011). Then, we generated a functional dendrogram, which was used to calculate the MPD and MNTD indices. The MPD is the average of the distances between pairs of species that co-occur in the community, and it is sensitive to changes

TABLE 1 | Description of five functional traits and 22 trait categories used to characterize fish species, including aspects of ecology, feeding behavior and habitat use. ${ }^{1}$ Casatti (2002), Casatti et al. (2003), and Teresa, Casatti (2012). ${ }^{2}$ Casatti et al. (2001), Casatti (2002) and personal observations. 
closer to the dendrogram root. The MNTD represents the average distance between the nearest species pairs and is more sensitive to changes in the terminal branches of the dendrogram (Webb, 2000). Indices were calculated in the $\mathrm{R}$ software (R Development Core Team, 2012) using the picante package (Kembel et al., 2010).

Data analysis. To evaluate the changes in water depth, flow, and instream habitat diversity, we compared the values of pre- and post-restoration periods by using a dependent t-test for each variable. Before all analysis, we evaluated the assumptions of normality and homoscedasticity by using a graphical inspection of residuals and the Levene's test, respectively.

We compared the patterns of taxonomic and functional diversity among reaches and between pre- and post-restoration periods by using a two-way Analysis of Variance (ANOVA), with treatments (C, W, and WL) and periods (pre- and post-restoration) as within-subject factors.

We tested the effects of periods (pre- and post-restoration) and treatments (C, $\mathrm{W}$, and $\mathrm{WL}$ ) in species composition, abundance, and functional composition of fish communities with a Permutational Multivariate Analysis of Variance (PERMANOVA). PERMANOVA tests for differences among factors were defined a priori (periods and treatments, in our case) having a dissimilarity matrix as a response variable. We used the Jaccard and Bray-Curtis coefficients to assemble the dissimilarity matrices of species composition and abundance, respectively. To assess functional composition, we used a dissimilarity matrix obtained from a Double Principal Coordinate Analysis (DPCoA) (Pavoine et al., 2004). The DPCoA analyzes the relationship between a matrix containing the functional differences among species (Euclidean distance) and a matrix containing species abundance across stream reaches (Pavoine et al., 2004). This analysis provides the dissimilarities among communities deduced by functional differences among species and their distribution across samples (Pavoine et al., 2004).

Complementarily, we assessed whether the changes in species composition, abundance and functional composition between pre- and post restoration periods (i.e., the dissimilarity between periods) was greater in the W and WL reaches than in the Control by using an ANOVA with repeated measures, complemented by the Tukey post-hoc test. The dissimilarity in species composition and abundance was assessed by the Jaccard and Bray-Curtis dissimilarity coefficients, respectively, calculated between the two periods for each stream reach (they were obtained by subtracting the similarity indices from 1). We obtained the functional composition dissimilarity with a Double Principal Coordinate Analysis (DPCoA) (Pavoine et al., 2004). When differences were found, we plotted community patterns by using a Non-metric Multidimensional Scaling and performed a Similarity Percentage Analysis (SIMPER) to determine which species (or functional traits) contributed the most to the differences between periods (we highlighted species that contributed more than $5 \%$ to the dissimilarity between periods).

\section{RESULTS}

After the experimental period, the wood structures from two streams were buried by fine sediment (P2 and P5) (Fig. 3A), making resampling unfeasible. Hence, we removed 
these streams from our data set and performed the analyzes with the remaining six streams.

No significant changes in reach depth were registered between pre- and postrestoration periods (dependent t-test: $\mathrm{C}$ treatment $\mathrm{t}=1.014, \mathrm{df}=5, p=0.356 ; \mathrm{W}$ treatment $\mathrm{t}=0.096, \mathrm{df}=5, \mathrm{p}=0.927$; WL treatment $\mathrm{t}=0.405, \mathrm{df}=5, \mathrm{p}=0.702)$. Water flow, on the other hand, was reduced in the post-restoration period in all reaches, including the control reaches (C treatment $\mathrm{t}=3.241 ; \mathrm{df}=5, p=0.02 ; \mathrm{W}$ treatment $\mathrm{t}=4.209, \mathrm{df}=5$, $\mathrm{p}=0.008 ; \mathrm{WL}$ treatment $\mathrm{t}=1.571, \mathrm{df}=5, \mathrm{p}=0.088)$. Instream habitat diversity increased in the W and WL treatments ( $\mathrm{W}$ treatment $\mathrm{t}=-3.7, \mathrm{df}=5, \mathrm{p}=0.013$; WL treatment $\mathrm{t}=$ $-7.42, \mathrm{df}=5, \mathrm{p}=0.001)$, but not in $\mathrm{C}(\mathrm{t}=0.254, \mathrm{df}=5, \mathrm{p}=0.809)$ (Fig. 4). Organic matter retention was one of the major changes caused by woody debris addition; the presence of wood locally reduced water flow, creating patches of fine particulate organic matter (FPOM) deposits (compare Fig. 3B to Fig. 3C). Moreover, grasses from stream banks entered the instream habitat, using part of the structures as substrate, and items drifted by the current (mainly plant debris) were retained in the wire threads that bound the structures (Fig. 3D), expanding the range of habitat patches available for colonization. Periphyton and algae also colonized the wood structures by the end of the experiment (Fig. 3E-F).

A total of 1,695 fish belonging to 36 species and five orders were collected (Tab. S1, available only in the online version). The functional traits of the sampled species can be viewed in Tab. S2, available only in the online version. There were no significant effects of periods, treatments or interactive effects of periods and treatments on the taxonomic (richness and Shannon diversity) or functional (MPD and MNTD) diversity (two-way ANOVA, $p>0.08$ ) (for detailed statistical results see Tab. 2 and Tab. S3, available only in the online version). Similarly, species composition, abundance, and functional composition were not significantly different between pre- and post-restoration periods and among reaches (PERMANOVA, $p>0.54$ ) (Tab. S3, available only in the online version). Changes in species composition and functional composition for each stream reach were also not significant (repeated measures ANOVA, $p=0.13$ ). However, species abundance (pairwise dissimilarity) was significantly different among reaches in the pre- and post-restoration periods (repeated measures ANOVA, $\mathrm{F}_{2,10}=6.29, p=$ 0.01). Specifically, changes of species abundance and composition in WL were greater than in C (Tukey post-hoc test, $p=0.01$ ) (Fig. 4). The higher dissimilarity between preand post-restoration periods in the WL reach resulted from the decreased abundance of Piabina argentea Reinhardt, 1867, Poecilia reticulata Peters, 1859, Aspidoras fuscoguttatus Nijssen, Isbrücker, 1976, Imparfinis schubarti (Gomes, 1956), and Astyanax cf. paranae Eigenmann, 1914, and increased abundance of Cetopsorhamdia iheringi Schubart, Gomes 1959, Hypostomus variipictus (Ihering, 1911), Hisonotus francirochai (Ihering, 1928), and Oligosarcus pintoi Amaral Campos, 1945 in the post-restoration period (Tab. 3).

\section{DISCUSSION}

The results revealed that the addition of woody structures and leaf packs promoted a significant increase in habitat diversity and organic matter retention, corroborating our first prediction. However, in the short term (112 days), these modifications were not 

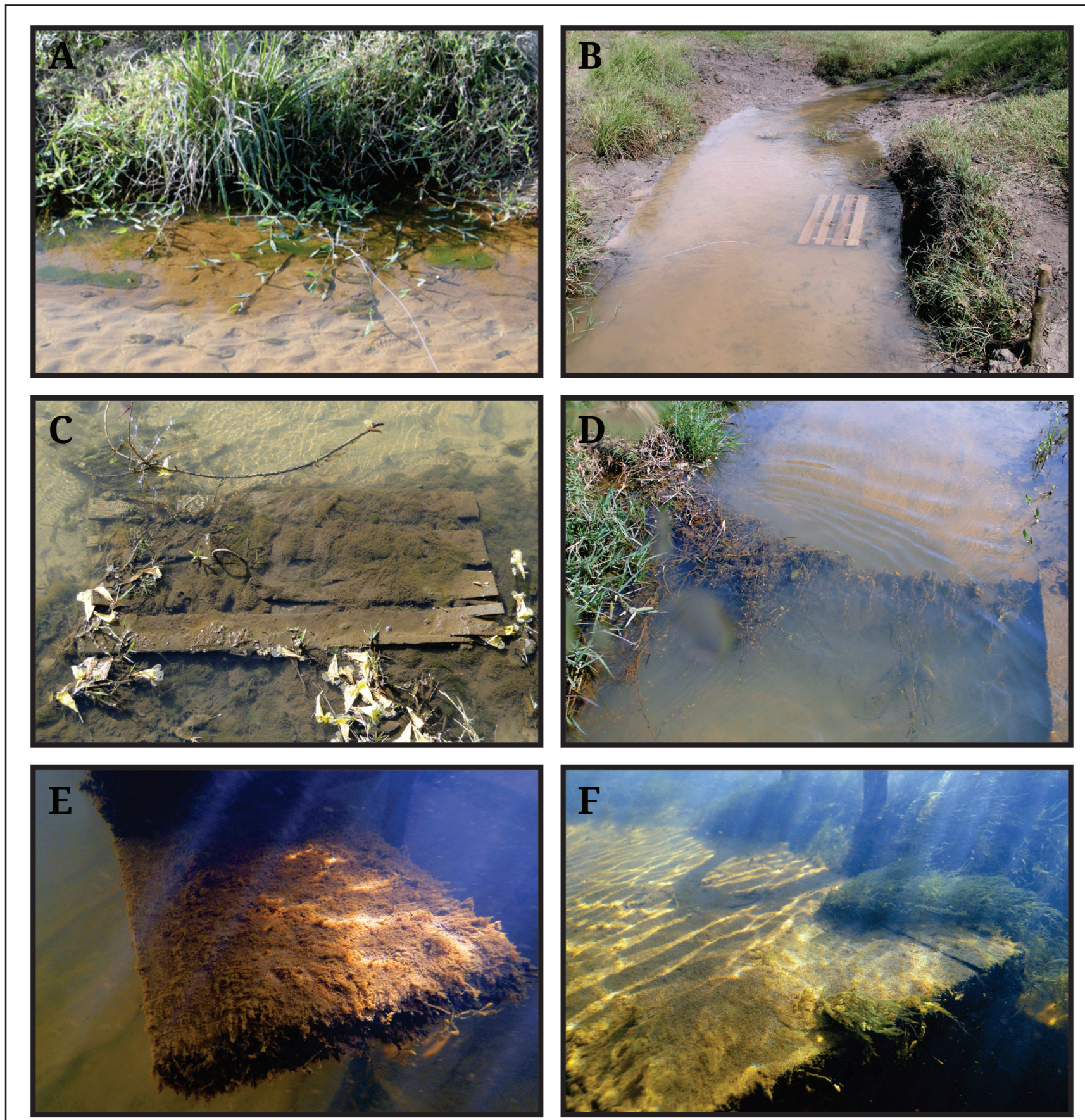

FIGURE 3 I Physical changes in stream reaches: A. Picture of the buried structure in P2; B. P3 stream reach at the beginning of the experiment; C. P3 stream reach at the end of the experiment, illustrating organic matter retention by the woody structure; D. macrophytes retention by wire in P8; E. growth of periphyton on the wood; F. growth of algae on the wood.

enough to significantly affect stream fish community structure, except for a change in species abundance in reaches with the addition of wood and leaves. Changes in species abundance are one of the first community-level alterations in response to environmental 

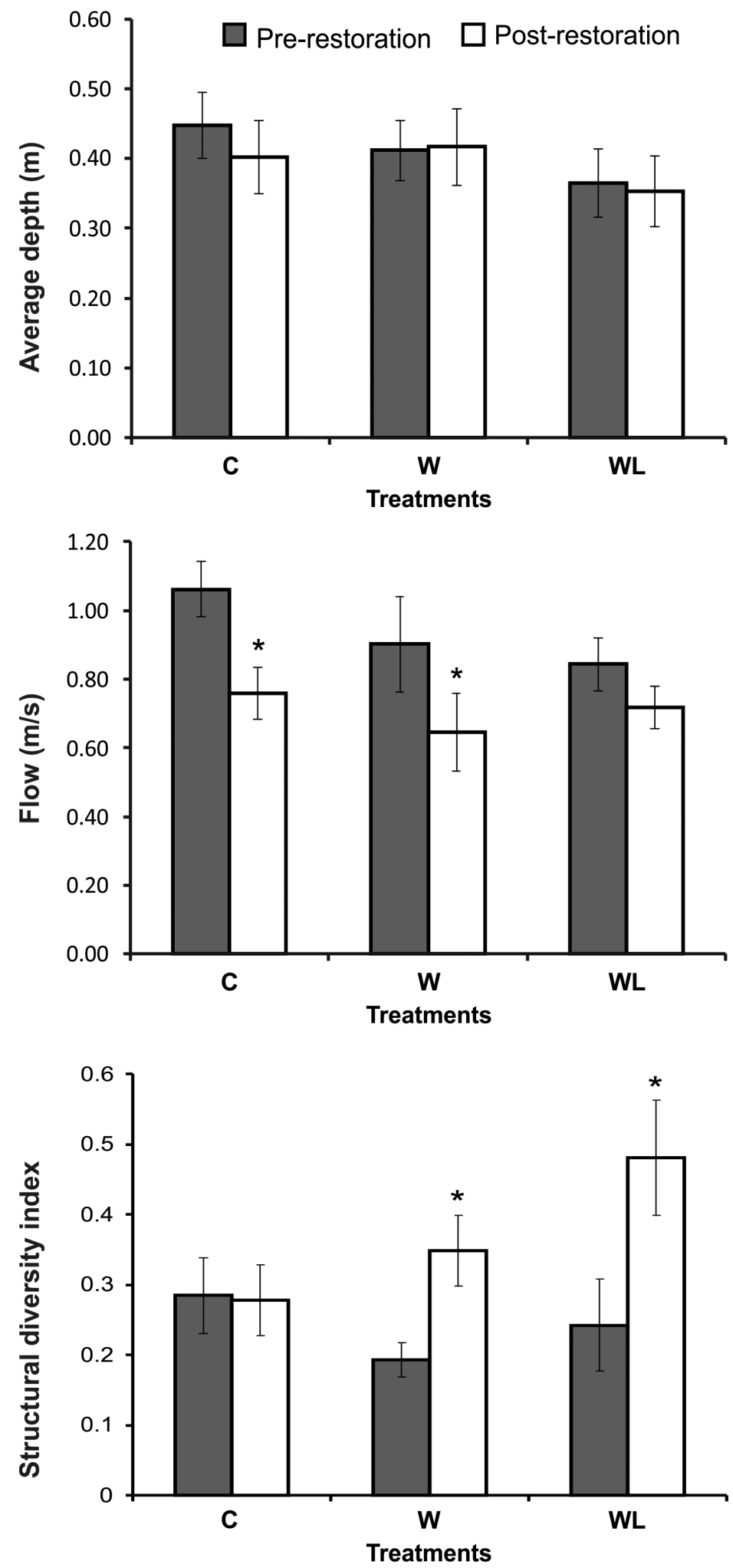

FIGURE 4 I Changes in environmental parameters (mean $\pm \mathrm{sd}$ ) depth, flow and structural diversity in pre and post-restoration conditions. $\mathrm{C}=\mathrm{Control}$ treatment, $\mathrm{W}=\mathrm{Wood}$ treatment, $\mathrm{WL}=\mathrm{Wood} / \mathrm{leaf}$ treatment, ${ }^{*}=$ p-values $<0,05$. 
TABLE 2 I Taxonomic and functional diversity of stream fish communities in each stream (P1-P8), for the pre- and post-restoration periods, and across the three treatments (Control, Wood and Wood/Leaf). Mean and standard deviation (sd) are also shown.

\begin{tabular}{|c|c|c|c|c|c|c|c|}
\hline \multirow{2}{*}{$\begin{array}{l}\text { Response } \\
\text { variable }\end{array}$} & \multirow{2}{*}{ Sites } & \multicolumn{2}{|c|}{ Control } & \multicolumn{2}{|c|}{ Wood } & \multicolumn{2}{|c|}{ Wood/Leaf } \\
\hline & & Pre & Post & Pre & Post & Pre & Post \\
\hline \multirow{7}{*}{ 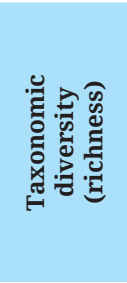 } & $\mathrm{P} 1$ & 6 & 7 & 10 & 9 & 8 & 8 \\
\hline & P3 & 6 & 3 & 3 & 3 & 5 & 4 \\
\hline & P4 & 8 & 7 & 7 & 12 & 6 & 8 \\
\hline & P6 & 4 & 10 & 7 & 6 & 5 & 10 \\
\hline & P7 & 10 & 7 & 9 & 6 & 5 & 5 \\
\hline & P8 & 9 & 10 & 12 & 5 & 8 & 6 \\
\hline & Mean \pm sd & $7.2 \pm 2.2$ & $7.3 \pm 2.6$ & $8.0 \pm 3.1$ & $6.8 \pm 3.2$ & $6.2 \pm 1.5$ & $6.8 \pm 2.2$ \\
\hline \multirow{7}{*}{ 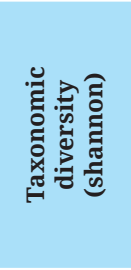 } & $\mathrm{P} 1$ & 1.39 & 1.48 & 2.02 & 2.02 & 1.66 & 1.44 \\
\hline & P3 & 0.61 & 0.29 & 0.79 & 0.95 & 1.34 & 1.21 \\
\hline & $\mathrm{P} 4$ & 1.37 & 1.25 & 1.51 & 2.04 & 1.59 & 1.92 \\
\hline & P6 & 1.07 & 1.72 & 1.61 & 1.61 & 1.61 & 1.96 \\
\hline & P7 & 1.71 & 1.70 & 1.73 & 1.43 & 1.23 & 1.44 \\
\hline & P8 & 1.69 & 1.76 & 2.01 & 1.36 & 1.82 & 1.54 \\
\hline & Mean \pm sd & $1.30 \pm 0.41$ & $1.37 \pm 0.56$ & $1.61 \pm 0.45$ & $1.57 \pm 0.42$ & $1.54 \pm 0.22$ & $1.58 \pm 0.30$ \\
\hline \multirow{7}{*}{ 胥会 } & $\mathrm{P} 1$ & 0.65 & 0.63 & 0.75 & 0.74 & 0.72 & 0.76 \\
\hline & P3 & 0.75 & 0.68 & 0.82 & 0.82 & 0.70 & 0.81 \\
\hline & $\mathrm{P} 4$ & 0.61 & 0.71 & 0.71 & 0.72 & 0.68 & 0.75 \\
\hline & P6 & 0.74 & 0.73 & 0.74 & 0.74 & 0.76 & 0.74 \\
\hline & P7 & 0.75 & 0.67 & 0.72 & 0.73 & 0.73 & 0.72 \\
\hline & P8 & 0.73 & 0.74 & 0.74 & 0.69 & 0.69 & 0.73 \\
\hline & Mean \pm sd & $0.70 \pm 0.06$ & $0.69 \pm 0.04$ & $0.75 \pm 0.04$ & $0.73 \pm 0.06$ & $0.71 \pm 0.03$ & $0.75 \pm 0.03$ \\
\hline \multirow{7}{*}{ 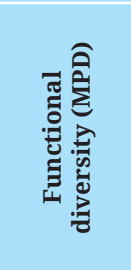 } & $\mathrm{P} 1$ & 0.18 & 0.42 & 0.35 & 0.33 & 0.36 & 0.41 \\
\hline & P3 & 0.46 & 0.54 & 0.82 & 0.82 & 0.31 & 0.77 \\
\hline & $\mathrm{P} 4$ & 0.19 & 0.35 & 0.48 & 0.38 & 0.50 & 0.49 \\
\hline & P6 & 0.60 & 0.43 & 0.38 & 0.48 & 0.60 & 0.35 \\
\hline & P7 & 0.48 & 0.38 & 0.37 & 0.45 & 0.48 & 0.45 \\
\hline & P8 & 0.37 & 0.41 & 0.37 & 0.38 & 0.29 & 0.36 \\
\hline & Mean \pm sd & $0.38 \pm 0.17$ & $0.42 \pm 0.06$ & $0.46 \pm 0.18$ & $0.47 \pm 0.18$ & $0.43 \pm 0.12$ & $0.47 \pm 0.16$ \\
\hline
\end{tabular}

TABLE 3 I Species contribution to dissimilarity between the pre- and post-retoration periods of the Wood/Leaf treatment. a = Contribution of each species to the mean dissimilarity between groups. $\mathrm{b}=$ Mean dissimilarity between groups \pm standard deviation. $\mathrm{c}=$ Contribution percentage of each species (> 5.0\%) to the dissimilarity between groups.

\begin{tabular}{|c|c|c|c|c|}
\hline \multirow{2}{*}{ Species } & \multicolumn{2}{|c|}{ Mean abundance $^{a}$} & \multirow{2}{*}{ Mean dissimilarity ${ }^{b}$} & \multirow{2}{*}{ Contribution $\%^{c}$} \\
\hline & Pre & Post & & \\
\hline Piabina argentea & 0.13 & 0.11 & $8.74 \pm 0.98$ & 11.61 \\
\hline Poecilia reticulata & 0.17 & 0.1 & $7.67 \pm 1.32$ & 10.19 \\
\hline Cetopsorhamdia iheringi & 0.04 & 0.12 & $6.53 \pm 0.86$ & 8.67 \\
\hline Aspidoras fuscoguttatus & 0.12 & 0.03 & $5.82 \pm 0.94$ & 7.73 \\
\hline Imparfinis schubarti & 0.14 & 0.1 & $5.8 \pm 1.42$ & 7.71 \\
\hline Astyanax cf. paranae & 0.1 & 0.06 & $5.46 \pm 1.01$ & 7.26 \\
\hline Hypostomus variipictus & 0 & 0.1 & $5.15 \pm 0.46$ & 6.84 \\
\hline Oligosarcus pintoi & 0.01 & 0.09 & $4.87 \pm 0.55$ & 6.47 \\
\hline Hisonotus francirochai & 0 & 0.08 & $3.8 \pm 0.92$ & 5.05 \\
\hline
\end{tabular}


variations (Mouillot et al., 2013), occurring either before declining species become locally extinct or before favored species have already colonized the habitat. Notwithstanding, the restoration effort was not sufficient to change taxonomic diversity or the functional structure of fish assemblages, refuting our second and fourth predictions. These results indicate that small-scale physical habitat restoration with wood structures and leaf packs has subtle effects on the ichthyofauna of heavily degraded regions. The studied streams are located in areas with strong anthropogenic influence and high soil erosion susceptibility (Silva et al., 2007), so that siltation is one of the primary impacts limiting aquatic communities (Casatti et al., 2015). The burial of the wood structures in two reaches illustrates the intensity of sediment inputs and discharge and demonstrates how habitat homogenization can be a rapid and continuous process in deforested watersheds, with the power to hamper other restoration strategies.

Fish species composition, abundance, and functional composition did not differ among periods and reaches, but combined changes in species abundance and composition between pre- and post restoration periods were greater in WL reaches. This apparent mismatch may be explained by i) a high inter-stream variability that is greater than the resulting effect of period and treatments, so that differences could not be captured by the PERMANOVA analysis; ii) an idiosyncratic response of communities to restoration in the WL reaches. In this case, changes in species abundance after restoration occurred in a nondirectional way, with communities of each stream responding differently (Matthews et al., 2013). The reach-specific response, illustrated by different trajectories of communities at post-restoration period (shown as arrows in Fig. 4), apparently amplified the inter-stream variability, resulting in the absence of a clear differentiation among reaches.

The local scale of the experiment (5-meter reaches) and the short experimental duration (112 days) may also have influenced the little restoration effects observed. Many studies have shown that macroinvertebrate colonization of litter bags takes only a few days (e.g., Janke, Trivinho-Strixino, 2007; Ligeiro et al., 2010; Moulton et al., 2010). Since macroinvertebrates are the primary food for several fish species, we believed that this timescale of intervention would be sufficient to promote changes in fish community. In addition, a recent study (Ceneviva-Bastos et al., 2017) with a very similar experimental design found that three months were enough to allow the colonization of woody debris and litter bags by macroinvertebrates and fish, promoting food web complexity in terms of links and species; however, responses from macroinvertebrates were more prominent than those of fish (Ceneviva-Bastos et al., 2017). Differential species responses to restoration depend on how restoration procedures influence niche- and dispersal-based processes. For example, the improvement of stream network connectivity would favor the dispersion to previously inaccessible but suitable habitats (Höckendorff et al., 2017). On the other hand, restoration practices that include changes in local environmental conditions can make suitable reaches that were previously unsuitable for several stream fishes (Shirey et al., 2016). The processes involved in the latter were probably more influential to our study system, as our restoration practices were designed to improve local physical habitat complexity rather than enhance connectivity.

The four species with increased abundance in the restored reaches are known to require specific habitat conditions, partially corroborating our third prediction. Among them, Hisonotus francirochai and Oligosarcus pintoi are usually associated with macrophytes. The first uses macrophytes to graze on epiphyton; the second is an ambush 
predator of invertebrates (Casatti, 2002). The other two species, Hypostomus variipictus and Cetopsorhamdia iheringi, are bottom dwellers associated with hard substrates; the first is a detritivore grazer and the second is a substrate speculator insectivore (Teresa, Casatti, 2012). Conversely, species with reduced abundance after restoration included the generalist drift feeders Astyanax cf. paranae and Piabina argentea, and also species that are tolerant to hypoxia, often associated with silted habitats, such as Poecilia reticulata and Aspidoras fuscoguttatus (Teresa, Casatti, 2012). Interestingly, one of the species that decreased in abundance was Poecilia reticulata, a non-native species in the studied area. After the restoration, the reduction of the abundance of $P$. reticulata is possibly due to the decrease in the availability of the main microhabitat explored by this species, which are small pools close to the streambanks (e.g., Roa-Fuentes, Casatti, 2017). These results indicate that the experimental debris and leaf packs provided better habitat conditions for more sensitive species and probably influenced the interactions among organisms to the point of affecting the abundance of non-native species (e.g., biotic resistance effect, Elton, 1958). However, the assessment of functional traits at the community level did not capture the observed variation in species abundance between periods. Most sampled species were little affected by treatments, so the influence of a few sensitive species may not have been enough to influence overall functional patterns of the community. Furthermore, it is possible that species' responses were driven by functional traits with a higher resolution than those used herein (Laughlin, 2014), or by a specific combination of traits rather than considering all of them (Saito et al., 2016).

Recovery strategies should target different spatiotemporal scales. First, it is necessary to protect areas with high-quality habitats (i.e., refugia with key habitats and high diversity and abundance of native species) to ensure a diversified regional species pool. Second, long-term monitoring actions following restoration should be encouraged. For instance, many studies have shown that fish respond positively to changes on a mesohabitat scale, which includes distinct key habitats such as resting or reproductive areas (Lorenz et al., 2013; Hickford, Schiel, 2014), but those positive results only appeared after eight years, on average, following restoration (e.g., Lepori et al., 2005b; Morandi et al., 2014). Based on these trends, changes in species richness and functional diversity would appear over a longer timespan (if the regional species pool is not entirely depleted), though it would probably require habitat manipulation on a broader spatial scale.

The response of aquatic biodiversity to restoration depends not only on habitat complexity itself, but also on the quality of the regional species pool (Palmer et al., 2010). In regions with a diversified regional species pool, some species can overcome dispersal and habitat constraints and become part of the restored community (Lake et al., 2007). Nevertheless, the loss of sensitive and specialist species concurs with the dominance of highly tolerant opportunistic species in regions where impacts are severe (Scott, Helfman, 2001). In this scenario, restoring the physical habitat would not promote species addition to local assemblages (Lake et al., 2007) because potential colonizers in neighboring communities are absent (Sunderman et al., 2011; Stoll et al., 2013). Thus, it is also possible that the lack of response of species diversity to restoration observed in our study was due to a long-term homogenization of neighboring communities, with loss of potential colonizers and dispersal constraints. The homogenization of stream fish assemblages was reported by previous studies conducted in the region (Casatti et al., 2015; Teresa, Casatti, 2017). Indeed, the studied region has been historically impacted 
and remaining forests are limited to few, sparse, and unconnected fragments, and such degradation extends to the riparian buffer (Silva et al., 2007). Therefore, in these degraded conditions, recolonization will be affected by this reduced regional species pool. Such regional (and riparian) degradation would affect the local scale dynamic and, consequently, the success of restoration efforts.

Synergetic restoration measures including the recovery of water quality (by reducing or stopping the pollutant discharge), the restoration of the watershed and riparian forest cover, habitat connectivity improvement, floodplain connection, and the control of soil erosion, are necessary to ensure proper conditions and resources for the aquatic biota (Roni et al., 2008; Palmer et al., 2010; Lorenz et al., 2013). Nevertheless, the combination of all these actions can only be possible if encouraged and supported by adequate public policies. Meanwhile, we encourage additional studies about stream restoration in Brazil. New attempts should consider the recovery of riparian forests and ways to promote regional connectivity combined with instream manipulation on a broader scale (e.g., by covering a larger area with woody debris) and test the efficiency of different materials (e.g., large wood, bricks or rocks). Even in a small spatial scale and relatively short period, our results showed that the addition of woody debris and leaf packs in heavily impacted streams can change fish abundance, increasing the abundance of more sensitive species and decreasing the abundance of generalist species. These results can represent a first step towards a better understanding of habitat restoration for stream fishes in the Neotropical region.

\section{ACKNOWLEDGEMENTS}

We thank the Ichthyology Lab colleagues for their help during fieldwork and the Department of Zoology and Botany of IBILCE-UNESP for facilities; IBAMA for collecting license; landowners for permission to conduct research in their properties, Pablo A. P. Antiqueira for help with statistical analysis and Francisco Langeani, Denise de Cerqueira Rossa-Feres, Cristina da Silva Golçalves and Paulo dos Santos Pompeu for valuable suggestions. This study was financed in part by the Coordenação de Aperfeiçoamento de Pessoal de Nível Superior - Brasil (CAPES) - Finance Code 001, MCB received grant from FAPESP (2011/11641-1), and FBT and LC are currently funded by CNPq (306912/2018-0 and 301877/2017-3, respectively).

\section{REFERENCES}

- Achard F, Eva HD, Stibig HJ, Mayaux P, Gallego J, Richards T, Malingreau JP. Determination of deforestation rates of the world's humid tropical forests. Science. 2002; 297(5583):999-1002. http://dx.doi. org/10.1126/science.1070656

- Allan JD, Castillo MM. Stream ecology: structure and function of runing Waters. London: Chapman \& Hall. 2007.
- Alvares CA, Stape JL, Sentelhas PC, Gonçalves JLM, Sparovek G. Köppen's climate classification map for Brazil. Meteorol Z. 2014; 22(6):711-28. https://doi. org/10.1127/0941-2948/2013/0507

- Bond NR, Lake PS. Characterizing fishhabitat associations in streams as the first step in ecological restoration. Austral Ecol. 2003; 28(6):611-21. https://doi. org/10.1046/j.1442-9993.2003.t01-1-01317.x 
- Bond NR, Lake PS. Ecological restoration and large-scale ecological disturbance: the effects of drought on the response by fish to a habitat restoration experiment. Restor Ecol. 2005; 13(1):39-48. https://doi. org/10.1111/j.1526-100X.2005.00006.x

- Boyero L, Ramírez A, Dudgeon RD, Pearson RG. Are tropical streams really different? J N Am Benthol Soc. 2009; 28(2):397-403. https://doi.org/10.1899/08146.1

- Britski HA, Silmon KZS, Lopes BS. Peixes do Pantanal: Manual de identificação. Brasília: Embrapa; 2007.

- Brooks AP, Gehrke P, Jansen JD, Abbe TB. Experimental reintroduction of woody debris on the Williams River, NSW: Geomorphic and ecological responses. River Res Appl. 2004; 20(5):513-36. https:// doi.org/10.1002/rra.764

- Buckup PA, Menezes NA, Ghazzi MS. Catálogo das espécies de peixes de água doce do Brasil. Rio de Janeiro: Museu Nacional; 2007.

- Casatti L. Alimentação dos peixes em um riacho do Parque Estadual Morro do Diabo, bacia do Alto Rio Paraná, sudeste do Brasil. Biota Neotrop. 2002; 2(2):1-15. https://doi. org/10.1590/S1676-06032002000200012

- Casatti L, Langeani F, Castro RMC. Peixes de riacho do Parque Estadual Morro do Diabo, bacia do alto rio Paraná, SP. Biota Neotrop. 2001; 1:1-15. https://doi. org/10.1590/S1676-06032001000100005

- Casatti L, Mendes HF, Ferreira KM. Aquatic macrophytes as feeding site for small fishes in the Rosana reservoir, Paranapanema river, southeastern Brazil. Braz J Biol. 2003; 63(2):213-22. https://doi. org/10.1590/S1519-69842003000200006

- Casatti L, Teresa FB, Zeni JO, Domiciano MR, Brejão GL, Ceneviva-Bastos M. More of the same: high functional redundancy in stream fish assemblages from tropical agroecosystems. Environ Manage. 2015; 55:1300-14. https://doi.org/10.1007/s00267015-0461-9

- Castro RMC, Casatti L, Santos HF, Ferreira KM, Ribeiro AC, Benine RC, Dardis GZP, Melo ALA, Stopiglia R, Abreu TX, Bockmann FA, Carvalho M, Gibran FZ, Lima FCT. Estrutura e composição da ictiofauna de riachos do rio Paranapanema, Sudeste e Sul do Brasil. Biota Neotrop. 2003; 3(1):1-31. https://doi. org/10.1590/S1676-06032003000100007
- Ceneviva-Bastos M, Montaña CG, Schalk CM, Camargo PB, Casatti L. Responses of aquatic food webs to the addition of structural complexity and basal resource diversity in degraded Neotropical streams. Austral Ecol. 2017; 42(8):908-19. https://doi. org/10.1111/aec.12518

- Centro Integrado de Informações Agrometereológicas (CIIAGRO).

Monitoramento climatológico da estação EMA 2011 [Internet] Available from: https://www.udop.com.br/download/ estatistica/economia_chuvas/2008a2019_ historico_sjose_rio_preto.pdf

- Cetra M, Petrere M, Barrella W. Relative influences of environmental and spatial factors on stream fish assemblages in Brazilian Atlantic rainforest. Fisheries Manag Ecol. 2017; 24(2):139-45. https://doi. org/10.1111/fme.12207

- Crook DA, Robertson AI. Relationships between riverine fish and woody debris: implications for lowland rivers. Mar Freshwater Res. 1999; 50(8):941-53. https:// doi.org/10.1071/MF99072

- Cruz BB, Miranda LE, Cetra M. Links between riparian landcover, instream environment and fish assemblages in headwater streams of south-eastern Brazil. Ecol Freshw Fish. 2013; 22(4):607-16. https://doi.org/10.1111/eff.12065

- Elton CS. The ecology of invasions by animals and plants. London: Methuen; 1958.

- Flores L, Larrañaga A, Díez J, Elosegi A. Experimental wood addition in streams: effects on organic matter storage and breakdown. Freshwater Biol. 2011; 56(10):2156-67. https://doi.org/10.1111/ j.1365-2427.2011.02643.x

- Froese R., Pauly D. FishBase. World Wide Web electronic publication [Internet]. 2019. Available from: www.fishbase.org.

- Gorman T, Karr JR. Habitat structure and fish communities. Ecology. 1978; 59(3):507-15. https://doi. org/10.2307/1936581

- Hickford MJH, Schiel DR. Experimental rehabilitation of degraded spawning habitat of a diadromous fish, Galaxias maculatus (Jenyns, 1842) in rural and urban streams. Restor Ecol. 2014; 22(3):319-26. https://doi.org/10.1111/ rec.12079 
- Höckendorff S, Tonkin JD, Haase P, Bunzel-Drüke M, Zimball O, Scharf M, Stoll S. Characterizing fish responses to a river restoration over 21 years based on species' traits. Conserv Biol. 2017; 31(5):1098-108. https://doi.org/10.1111/ cobi.12908

- IPT - Instituto de Pesquisas Tecnológicas do Estado de São Paulo. Diagnóstico da situação dos recursos hídricos da bacia hidrográfica do Turvo-Grande UGRHI-15. São Paulo; 2018. Available from: http://www.comitetg.sp.gov.br/cbhtg/ attachments/article/175/RS_CBH-TG_2018. pdf

- Janke H, Trivinho-Strixino S. Colonization of leaf litter by aquatic macroinvertebrates: a study in a low order tropical stream. Acta Limnol Bras. 2007; 19(1):109-15.

- Kembel SW, Cowan PD, Helmus MR, Cornwell WK, Morlon H, Ackerly DD, Blomberg SP, Webb Co. Picante: R tools for integrating phylogenies and ecology. Bioinformatics. 2010; 26(11):1463-64. https://doi.org/10.1093/bioinformatics/ btq166

- Kondolf GM. Lessons learned from river restoration projects in California. Aquat Conserv. 1998; 8(1):39-52. https://doi.org/10.1002/ (SICI)1099-0755(199801/02)8:1<39::AIDAQC250>3.0.CO;2-9

- Lake PS, Bond N, Reich P. Linking ecological theory with stream restoration. Freshwater Biol. 2007; 52(4):597-615. https://doi.org/10.1111/j.13652427.2006.01709.x

- Langford TEL, Langford J, Hawkins SJ. Conflicting effects of woody debris on stream fish populations: implications for management. Freshwater Biol. 2012; 57(5):1096-11. https://doi.org/10.1111/ j.1365-2427.2012.02766.x

- Laughlin DC. The intrinsic dimensionality of plant traits and its relevance to community assembly. J Ecol. 2014; 102(1):186-93. https://doi.org/10.1111/1365 2745.12187

- Lepori F, Palm D, Brännäs E, Malmqvist B. Does restoration of structural heterogeneity in streams enhance fish and macroinvertebrate diversity? Ecol Appl. 2005b; 15(6):2060-71. https://doi. org/10.1890/04-1372
- Lepori F, Palm D, Malmqvist B. Effects of stream restoration on ecosystem functioning: detritus retentiveness and decomposition. J Appl Ecol. 2005a; 42(2):228-38. https://doi.org/10.1111/j.13652664.2004.00965.x

- Ligeiro R, Moretti MS, Gonçalves JF, Callisto M. What is more important for invertebrate colonization in a stream with low-quality litter inputs: exposure time or leaf species? Hydrobiologia. 2010; 654(1):125-36. https://doi.org/10.1007/ s10750-010-0375-8

- Lorenz AW, Stoll S, Sundermann A, Haase P. Do adult and YOY fish benefit from river restoration measures? Ecol Eng. 2013; 61:174-81. https://doi.org/10.1016/j. ecoleng.2013.09.027

- Lorion CM, Kennedy BP. Riparian forest buffers mitigate the effects of deforestation on fish assemblages in tropical headwater streams. Ecol Appl. 2009; 19(2):468-79. https://doi.org/10.1890/08-0050.1

- Matthews WJ, Marsh-Matthews E, Cashner RC, Gelwick F. Disturbance and trajectory of change in a stream fish community over four decades. Oecologia. 2013; 173(3):955-69. https://doi.org/10.1007/ s00442-013-2646-3

- Morandi B, Piégay H, Lamouroux N, Vaudor L. How is success or failure in river restoration projects evaluated? Feedback from French restoration projects. J Environ Manage. 2014; 137:178-88. https://doi.org/10.1016/j. jenvman.2014.02.010

- Mouillot D, Graham NAJ, Villéger S, Mason NWH, Bellwood DR. A functional approach reveals community responses to disturbances. Trends Ecol Evol. 2013; 28(3):167-77. https://doi.org/10.1016/j. tree.2012.10.004

- Moulton TP, Magalhaes-Fraga SA, Brito EF, Barbosa FA. Macroconsumers are more important than specialist macroinvertebrate shredders in leaf processing in urban forest streams of Rio de Janeiro, Brazil. Hydrobiologia. 2010; 638(1):55-66. https://doi.org/10.1007/ s10750-009-0009-1 
- Nalon MA, Matto ISA, Franco GADC. Meio físico e aspectos da vegetação. In: Rodrigues RR, Bononi VLR, organizers. Diretrizes para conservação e restauração da biodiversidade no Estado de São Paulo. São Paulo: Instituto de Botânica; 2008. p.12-21. Available from: https:// www.sigam.ambiente.sp.gov.br/sigam3/ Repositorio/222/Documentos/Diretrizes conservacao_restauracao_biodiversidade. pdf

- Neumann RM, Wildman TL. Relationships between trout habitat use and woody debris in two southern New England streams. Ecol Freshw Fish. 2002; 11(2):240-50. https://doi.org/10.1034/j.1600 0633.2002.00016.x

- Ota RR, Deprá GC, da Graça WJ, Pavanelli CS. Peixes da planície de inundação do alto rio Paraná e áreas adjacentes: Revised, annotated and updated. Neotrop Ichthyol. 2018; 16(2):e170094. http://dx.doi. org/10.1590/1982-0224-20170094

- Palmer MA, Hondula KL, Koch BJ. Ecological restoration of streams and rivers: shifting strategies and shifting goals. Annu Rev Ecol Evol S. 2014; 45:247-69. https://doi.org/10.1146/annurevecolsys-120213-091935

- Palmer MA, Menninger HL, Bernhardt E. River restoration, habitat heterogeneity and biodiversity: a failure of theory or pratice? Freshwater Biol. 2010; 55:205-22. https://doi.org/10.1111/j.13652427.2009.02372.x

- Paula FR, Gerhard P, Wenger SJ, Ferreira A, Vettorazzi CA, Ferraz SFB. Influence of forest cover on instream large wood in an agricultural landscape of southeastern Brazil: a multi-scale analysis. Landscape Ecol. 2013; 28:13-27. https://doi. org/10.1007/s10980-012-9809-1

- Pavoine S, Bonsall M. Measuring biodiversity to explain community assembly: a unified approach. Biol Rev Camb Philos. 2011; 86(4):792-812. https:// doi.org/10.1111/j.1469-185X.2010.00171.x

- Pavoine S, Dufour AB, Chessel D. From dissimilarities among species to dissimilarities among communities: a double principal coordinate analysis. J Theor Biol. 2004; 228(4):523-37. https://doi. org/10.1016/j.jtbi.2004.02.014
- Pinto BCT, Araújo FG, Hughes RM. Effects of landscape and riparian condition on a fish index of biotic integrity in a large southeastern Brazil river. Hydrobiologia. 2006; 556:69-83. https://doi.org/10.1007/ s10750-005-9009-y

- Pretty JL, Harrison SSC, Shepherd DJ, Smith C, Hildrew AG, Hey D. River rehabilitation and fish populations: assessing the benefit of instream structures. J Appl Ecol. 2003; 40(2):25165. https://doi.org/10.1046/j.13652664.2003.00808.x

- Pusey BJ, Arthington AH. Importance of the riparian zone to the conservation and management of freshwater fish: a review. Mar Freshwater Res. 2003; 54(1):1-16. https://doi.org/doi:10.1071/mf02041

- R Development Core Team. R: a language and environment for statistical computing. Vienna, Austria: R Foundation for Statistical Computing; 2012. Available from: https://www.Rproject.org

- Reis RE, Kullander SO, Ferraris CJ Jr., editors. Check list of the freshwater fishes of South and Central America. Porto Alegre: Edipucrs; 2003.

- Ribeiro MD, Teresa FB, Casatti L. Use of functional traits to assess changes in stream fish assemblages across a habitat gradient. Neotrop Ichthyol. 2016; 14(1):e140185. https://doi.org/10.1590/19820224-20140185

- Ricklefs RE, Schulter D. Species diversity in ecological communities: historical and geographical perspectives. Chicago: University of Chicago Press; 1993.

- Roa-Fuentes CA, Casatti L. Influence of environmental features at multiple scales and spatial structure on stream fish communities in a tropical agricultural region. J Freshw Ecol. 2017; 32(1):281-95. https://doi.org/10.1080/02705060.2017.128 7129

- Roni P, Beechie T, Pess G, Hanson K. Wood placement in river restoration: fact, fiction, and future direction. Can J Fish Aquat Sci. 2015; 72(3):466-78. https://doi. org/10.1139/cjfas-2014-0344

- Roni P, Hanson K, Beechiê T. Global review of the physical and biological effectiveness of stream habitat rehabilitation techniques. N Am J Fish Manag. 2008; 28(3):856-90. https://doi. org/10.1577/M06-169.1 
- Saito VS, Cianciaruso MV, Siqueira T, Fonseca-Gessner AA, Pavoine S. Phylogenies and traits provide distinct insights about the historical and contemporary assembly of aquatic insect communities. Ecol Evol. 2016; 6(9):2925-37. https://doi.org/10.1002/ece3.2081

- Scealy JA, Mika SJ, Boulton AJ. Aquatic macroinvertebrate communities on wood in an Australian lowland river: experimental assessment of the interactions of habitat, substrate complexity and retained organic matter. Mar Freshwater Res. 2007; 58(2):153-65. http://dx.doi.org/10.1071/MF06105

- Schneider KN, Winemiller KO. Structural complexity of woody debris patches influences fish and macroinvertebrate species richness in a temperate floodplainriver system. Hydrobiologia. 2008; 610:23544. https://doi.org/10.1007/s10750-008-9438-5

- Scott MC, Helfman GS. Native Invasions, Homogenization, and the Mismeasure of Integrity of Fish Assemblages. Fisheries. 2001; 26(11):6-15. https://doi. org/10.1577/1548-8446(2001)026<0006:NIH ATM $>2.0 . \mathrm{CO} ; 2$

- Selego SM, Rose CL, Merovich Jr GT, Welsh SA, Anderson JT. Communitylevel response of fishes and aquatic macroinvertebrates to stream restoration in a third-order tributary of the Potomac River. Acta Oecol. 2012:753634. https://doi. org/10.1155/2012/753634

- Shirey PD, Brueseke MA, Kenny JB, Lamberti GA. Long-term fish community response to a reach-scale stream restoration. Ecol Soc. 2016; 21(3):11. http:// dx.doi.org/10.5751/ES-08584-210311

- Silva AM, Casatti L, Álvares CA, Leite AM, Martinelli LA, Durrant SF. Soil loss risk and habitat quality in streams of a meso-scale river basin. Sci Agric. 2007; 64(4):336-43. https://doi.org/10.1590/S010390162007000400004
- Stoll S, Sunderman A, Lorenz AW, Kail J, Haase, P. Small and impoverished regional species pools constrain colonization of restored river reaches by fishes. Freshwater Biol. 2013; 58(4):664-74. https:// doi.org/10.1111/fwb.12068

- Sunderman A, Stoll S, Haase P. River restoration success depends on the species pool of the immediate surroundings. Ecol Appl. 2011; 21(6):1962-71. https://doi. org/10.1890/10-0607.1

- Sweeney BW, Newbold JD. Streamside forest buffer width needed to protect stream water quality, habitat, and organisms: A literature review. J Am Water Resour As. 2014; 50(3):560-84. https://doi. org/10.1111/jawr.12203

- Teresa FB, Casatti L. Influence of forest cover and mesohabitats types on functional and taxonomic diversity of fish communities in Neotropical lowland streams. Ecol Freshw Fish. 2012; 21(3):433-42. https://doi.org/10.1111/j.16000633.2012.00562.x

- Teresa FB, Casatti L. Trait-based metrics as bioindicators: Responses of stream fish assemblages to a gradient of environmental degradation. Ecol Indic. 2017; 75:249-58. https://doi.org/10.1016/j. ecolind.2016.12.041

- Webb co. Exploring the phylogenetic structure of ecological communities: An example for rain forest trees. Am Nat. 2000; 156:145-55. https://dx.doi. org/10.1086/303378

- Winemiller KO, Fitzgerald DB, Bower LM, Pianka ER. Functional traits, convergent evolution, and periodic tables of niches. Ecol Lett. 2015; 18:737-51. https://doi.org/10.1111/ele.12462

- Wright JP, Flecker AS. Deforesting the riverscape: the effects of wood on fish diversity in a Venezuelan piedmont stream. Biol Conserv. 2004; 120(3):439-47. https://doi.org/10.1016/j.biocon.2004.02.022

\section{AUTHOR CONTRIBUTIONS}

Angelo Rodrigo Manzotti: Data curation, Investigation, Methodology, Writing (original draft).

Mônica Ceneviva-Bastos: Conceptualization, Investigation, Writing (review \& editing).

Fabrício Barreto Teresa: Data curation, Formal analysis, Writing (review \& editing).

Lilian Casatti; Conceptualization, Methodology, Project administration, Resources, Writing (review \& editing). 


\section{Neotropical |chthyology}

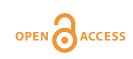

$$
\text { (c) (i) }
$$

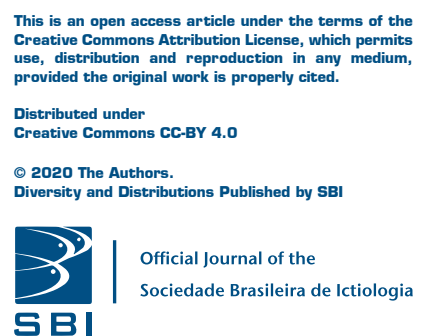

\section{ETHICAL STATEMENT}

All captured specimens (license number 11435) were euthanized by eugenol overexposure (300 $\mathrm{mg} / \mathrm{L}$ ), subsequently fixed in 10\% formalin solution and, after $48 \mathrm{~h}$, transferred to $70 \% \mathrm{EtOH}$ solution.

\section{COMPETING INTERESTS}

The authors declare no competing interests.

\section{ADDITIONAL INFORMATION}

Supplementary information accompanies this paper at http://www.sbi.bio.br/ni

HOW TO CITE THIS ARTICLE

- Manzotti AR, Ceneviva-Bastos M, Teresa FB, Casatti L. Short-term response of fish assemblages to instream habitat restoration in heavily impacted streams. Neotrop Ichthyol. 2020; 18(1):e190052. https://doi.org/10.1590/1982-0224-2019-0052 